\title{
Stents Convencionais versus Revestidos. A Polêmica Tem Razão de Ser?
}

\author{
Ver artigo relacionado \\ na página 117
}

\author{
Carlos A. M. Gottschall'
}

0 trabalho "Conflitos Éticos e Judiciais no Emprego dos Stents Farmacológicos no Brasil. Análise das Principais Controvérsias para Incorporação dessa Tecnologia nos Sistemas de Saúde Público e Privado no País", de Queiroga Lopes et al. ${ }^{1}$, suscita questões jurídicas, filosóficas e médicas dificilmente esgotadas numa única equação. Os autores expõem, com rara elegância e lucidez, as antinomias da escoIha de indicação de stents convencionais ou revestidos e os limites das respectivas preferências.

A precisa síntese do trabalho feita pelos autores afirma que os conflitos éticos e judiciais relativos ao emprego dos stents farmacológicos no Brasil decorrem principalmente do valor agregado desses dispositivos, cuja intensidade se reflete na economia em saúde e na relação custo-efetividade dos procedimentos. Assim, segurança e efetividade de stents convencionais contrapõem-se à visão correspondente dos stents farmacológicos, devendo-se buscar o equilíbrio entre os interesses coletivo e individual.

Assunto complexo e multifacetado, que, em tese, desafia a tríade composta por: o melhor benefício para o paciente, a escolha do médico baseada em evidências e na própria experiência, e o interesse pecuniário das seguradoras. A medicina não é uma ciência matemática exata, baseia-se em evidências que não são lineares. Por um lado, há o interesse de médico e paciente de que este se beneficie da indicação ideal; por outro, há a busca dos planos de saúde para assegurar a melhor relação custo-benefício. Numa linguagem mais popular, tal dilema poderia corresponder ao lençol curto. Se cobre o peito, deixa os pés de fora; se cobre os pés, deixa o peito desprotegido.

Do ponto de vista mais objetivo, a discussão cinge-se às melhores indicações de stent convencional e stent revestido. Considerando puramente os aspectos médicos, há indicações médicas consensuais (on label) e indicações em evolução bem respaldadas (off label). Entretanto, do ponto de vista científico, agarrar-se a modelos estáticos aborta o progresso, sabendo-se de condutas off label absolutamente bem indicadas, conforme demonstra a experiência universal. Do ponto de vista das seguradoras, a obediência indiscriminada a todas as opções faria ruir o sistema assistencial, consumindo-se recursos exageradamente com um único paciente, o que acabaria vedando possibilidades a outros indivíduos.

Felizmente, nota-se cada vez mais emergirem consensos na magistratura que dispensam rótulos jurídicos e enveredam pela jurisprudência do benefício. As seguradoras devem ter a necessária sensibilidade para acatar o indispensável, entendendo que a exceção justificada pode ser o único caminho. Se não houver esse entendimento, a justiça deve ser chamada e procurar preservar acima de tudo o princípio da beneficência da ética médica ou, pelo menos, da não-maleficência, colocando o princípio da equidade como um primado para equilibrar o interesse individual com o coletivo.

Direito é antes de tudo bom senso, entendendose essa expressão como equilíbrio de forças entre coletivo e privado. Quando se desvincula do equitativo passa a ser "regrismo" espúrio. Afortunadamente, vêse que a moderna justiça tende a dispensar considerações escolásticas, buscando prioritariamente o real benefício ao paciente e atendendo à melhor indicação médica, isto é, colocando o respeito à vida acima do respeito a fórmulas. Mas essa atitude não deve significar licença para superindicações totalmente alienadas da realidade econômica do País e das seguradoras. Não é motivado por exceções que se deve agir e sim por condutas alicerçadas nos princípios fundamentais da bioética - beneficência, autonomia e jus-

\footnotetext{
1 Laboratório de Hemodinâmica e Cardiologia Intervencionista do Instituto de Cardiologia/Fundação Universitária de Cardiologia de Porto Alegre (IC/FUC) - Porto Alegre, RS, Brasil.

Correspondência: Carlos A. M. Gottschall. Instituto de Cardiologia do Rio Grande do Sul - Unidade de Pesquisa. Av. Princesa Isabel, 370 - Santana - Porto Alegre, RS, Brasil - CEP 90620-001

E-mail: carlos.gottschall@cardiologia.org.br

Recebido em: 19/3/2009 • Aceito em: 20/3/2009
} 
tiça -, cumprindo à classe médica o direito e o dever de indicar a conduta mais adequada a determinado paciente.

Por outro lado, a maioria de bons praticantes da medicina não pode ser corporativa a ponto de desconhecer alguns exemplos de má prática médica na classe, responsáveis por provocar reações coercitivas por parte de convênios, seja por superindicarem procedimentos, seja por práticas fúteis. É até possível que esses casos sirvam como pretextos para exercer economia à custa da legião dos competentes. Cabe à classe médica e a seus órgãos fiscalizadores e normativos coibir as ações não recomendáveis por alguns de seus integrantes. Uma vez limpo o caminho, a credibilidade reconquistada deverá multiplicar forças para impor o justo, unindo-se medicina e direito, com a finalidade de conferir benefício ao paciente.

Torna-se imperativo atingir um ponto de equilíbrio entre custo-benefício, atendendo a indicações criteriosas pelos médicos quanto à real necessidade de tratamentos mais custosos. Se for a única e indispensável alternativa, assim seja feito. Se houver alternativa menos dispendiosa sem colocar em risco o paciente, esse aspecto deve ser considerado na decisão médica.
Nem sempre o progresso é "linear": progresso traz novas soluções, mas não sepulta condutas que continuam válidas em subgrupos de pacientes. É a situação dos que se beneficiam igualmente ou mais de stents convencionais que de stents revestidos. Por outra, em situações de indispensabilidade bem avaliada destes últimos, a indicação médica deve ser soberana, sob pena de violar-se o sagrado princípio ético da beneficência. Nesse caso, se necessário, o caminho é apelar para a justiça, até que surjam - como é desejado, buscado e esperado - normas legais transparentes e acatadas, capazes de incorporar as melhores e mais atualizadas indicações médicas.

\section{CONFLITO DE INTERESSES}

O autor declarou inexistência de conflito de interesses.

\section{REFERÊNCIA BIBLIOGRÁFICA}

1. Queiroga Lopes MAC, Queiroga Lopes Filho MAC, Gubolino LA, Mattos LA, Marin-Neto JA. Conflitos éticos e judiciais no emprego dos stents farmacológicos no Brasil. Análise das principais controvérsias para incorporação dessa tecnologia nos sistemas de saúde público e privado no País. Rev Bras Cardiol Invas. 2009;17(1):117-32. 